\title{
Detection of Haplosporidium nelsoni (Haplosporidia: Haplosporidiidae) in oysters by PCR amplification
}

\author{
Nancy A. Stokes, Mark E. Siddall, Eugene M. Burreson* \\ School of Marine Science, Virginia Institute of Marine Science, College of William and Mary, Gloucester Point, \\ Virginia 23062, USA
}

\begin{abstract}
Haplosporidium nelsoni is a protistan pathogen of the eastern oyster Crassostrea virginica, and has contributed to the decline of the oyster population in the Chesapeake Bay. From comparison of the sequence data of the 16S-like rDNA of $H$. nelsoni with those of Minchinia teredinis and other related organisms, 2 oligonucleotides which were specific to $H$. nelsoni and suitable for use as PCR primers were identified. These primers amplified a 564 base pair fragment of the small subunit (SSU) rRNA gene of $H$. nelsoni, but did not amplify genomic oyster DNA or the SSU rRNA genes of the haplosporidians Haplosporidium costale, Haplosporidium louisiana, or $M$. teredinis. The PCR primers were able to detect the $H$. nelsoni SSU rDNA from $50 \mathrm{ng}$ of infected oyster genomic DNA or from $10 \mathrm{fg}$ of cloned $H$. nelsoni SSU rDNA. The ability of the PCR primers to diagnose $H$. nelsoni-infected oysters was compared to the established techniques of hemolymph settlement analysis in Farley chambers and histological examination from a sample of 20 oysters. Hemolymph settlement analysis detected infection in 10 oysters and histology revealed infections in 11 oysters. PCR amplification of DNA from hemolymph initially detected infections in 15 oysters and reamplification of the PCR products detected an additional 4 infections. PCR amplification is a more sensitive diagnostic assay for $H$. nelsoni than traditional techniques.
\end{abstract}

KEY WORDS: Haplosporidium nelsoni $\cdot$ PCR $\cdot 16 \mathrm{~S}$-like rDNA $\cdot$ Disease detection

\section{INTRODUCTION}

The ability to rapidly and accurately detect parasites of oysters has broad implications for both research and industry. As rapid diagnostic methods become more sensitive, early detection of disease agents permits the management of oysters in a manner that is more responsive to patterns of naturally occurring diseases. The oyster pathogen Haplosporidium nelsoni, causing MSX disease, is widespread in the lower Chesapeake Bay, USA (Haskin \& Andrews 1988), where salinity is generally greater than 15 ppt. The widespread distribution and high virulence of $H$. nelsoni have greatly reduced traditional on-bottom culture and have limited the development of offbottom oyster aquaculture in high salinity areas.

\footnotetext{
-Addressee for correspondence; E-mail: gene@vims.edu
}

Early diagnosis of $H$. nelsoni infection is an essential management tool (Ford \& Haskin 1988). Thus, rapid, sensitive diagnostic assays may be critical in avoiding losses to the pathogen. Paraffin-based histological examination, the most commonly used diagnostic technique for $H$. nelsoni, involves finding parasite cells in one or two $5 \mu \mathrm{m}$ thick sections through an oyster's visceral mass, gills and mantle. There is a period of several weeks between the time early-summer $H$. nelsoni infections are heavy enough to be detected histologically and when mortality begins. Therefore, the earlier infections can be detected, the more time is available for oyster growers to decide whether to harvest to limit mortality, or whether to move oysters to low salinity to eliminate the parasite (Ford 1985). Infections of $H$. nelsoni acquired in late summer or fall remain nonlethal until spring; early detection would also allow harvest to avoid losses from these late season infections. 
Sensitive diagnostic assays would also enhance seed certification programs that strive to limit transfer of parasitized seed oysters to growout areas. At salinities of 10 to $15 \mathrm{ppt}$, Haplosporidium nelsoni may infect oysters but remain at nonlethal levels; however, if oysters are transferred to salinity greater than $15 \mathrm{ppt}$, infections may intensify and cause high mortality (Andrews 1964). Sensitive diagnostic assays that could detect very low intensity infections in spat or seed oysters could provide justification for not transferring oysters, thereby avoiding subsequent mortality.

Additionally, rapid, sensitive, nonlethal diagnostic techniques would facilitate long-term experiments to investigate the effect of various environmental variables or other parameters on infection progression and mortality. A nonlethal diagnostic technique involving settlement of cells in extracted hemolymph has been developed for Haplosporidium nelsoni, but is not as accurate as histology, especially at low infection intensities (Burreson et al. 1988, Ford \& Kanaley 1988). Repeated bleeding of hemolymph is known to cause sublethal changes in oysters, although it has not been observed to increase mortality when samples are taken every 2 wk (Ford 1986). Sublethal changes and mortality are probably a function of both the frequency of sampling and the amount of hemolymph withdrawn.

The development of polymerase chain reaction (PCR) amplification as a highly sensitive, potentially nonlethal diagnostic tool is promising. PCR protocols have been developed for diagnosis of the parasitic dinoflagellate Hematodinium sp. in various crustaceans (Hudson \& Adlard 1994) and for diagnosis of the haplosporidian Minchinia teredinis in woodboring molluscs (Stokes et al. 1995).

PCR diagnostic protocols will be especially valuable in elucidating complex parasite life cycles. With PCR, intermediate hosts can be identified by the amplification of parasite DNA from mixed host and parasite DNA extracted from the host; the morphology of the parasite or its location in the host does not have to be known. A complete life cycle is not known for any member of the phylum Haplosporidia. Failure of direct transmission in experiments using spores of Haplosporidium nelsoni from oysters to infect other oysters has led to speculation that an intermediate host may be a necessary component of life cycles in the Haplosporidia (Andrews 1984, Burreson 1988, Haskin \& Andrews 1988). The sensitivity of PCR amplification should allow rapid screening of a large number of potential intermediate hosts for DNA of $H$. nelsoni. Once an intermediate host is identified, a DNA probe already developed for $H$. nelsoni plasmodia (Stokes \& Burreson 1995) can be used to localize the parasite in the host for morphological studies and subsequent transmission experiments.
Hypervariable regions of the small subunit (SSU) or 16S-like ribosomal RNA genes of haplosporidians have been used for designing in situ hybridization probes (Fong et al. 1993, Stokes \& Burreson 1995, Stokes et al. 1995). Here we identify a pair of oligonucleotide primers from the SSU rRNA gene sequence of Haplosporidium nelsoni and investigate their sensitivity and specificity in amplifying $H$. nelsoni target DNA. Moreover, we compare PCR amplification as a nonlethal diagnostic technique for $H$. nelsoni in naturally infected oysters with traditional techniques of paraffin histology and hemolymph settlement.

\section{MATERIALS AND METHODS}

PCR primer selection. The Haplosporidium nelsoni SSU rDNA sequence [GenBank accession number U19538] was aligned with the SSU rDNA sequences of the haplosporidian Minchinia teredinis [U20319], the oyster Crassostrea virginica [X60315], and the oyster pathogen Perkinsus marinus [X75762] with the software package GeneJockeyII (Taylor 1993). The variable regions were examined for areas which appeared to be species specific and would be appropriate for use as PCR primers, as outlined by Innis \& Gelfand (1990). Putative primer sequences were also checked against the SSU rDNA sequences of the ciliates Oxytricha nova [X03948], Tetrahymena pyriformis [M98021], Stylonychia pustulata [M14600], and Paramecium tetraurelia [X03772], and the dinoflagellates Crypthecodinium cohnii [M64245], Symbiodinium corculorum [L13717], Prorocentrum micans [M14649], and Amphidinium belauense [L13719] within the GenBank database (Bilofsky \& Burks 1988). Following identification of suitable priming regions, the putative oligonucleotide sequences were sent as queries to the BLAST electronic mail server (blast@ncbi.nlm.nih.gov) to determine whether the primers would anneal to nontarget genes. Two oligonucleotides, designated MSX-A (5'GCATTAGGTTTCAGACC-3') and MSX-B (5'-ATGTGTTGGTGACGCTAACCG-3'), were selected and commercially synthesized (Genosys Biotechnologies, The Woodlands, TX, USA). The sequence of the MSX-B primer is the same as the $H$. nelsoni DNA probe MSX1347 described by Stokes \& Burreson (1995)

Primer sensitivity and specificity. $\mathrm{PCR}$ reaction mixtures contained reaction buffer $(10 \mathrm{mM}$ Tris- $\mathrm{HCl}$, $\mathrm{pH} 8.3,50 \mathrm{mM} \mathrm{KCl}, 1.5 \mathrm{mM} \mathrm{MgCl}_{2}, 10 \mu \mathrm{g} \mathrm{ml}^{-1}$ gelatin), 25 pmol of each primer, $200 \mu \mathrm{M}$ each of dATP, dCTP, dGTP, dTTP, 0.6 units AmpliTaq DNA polymerase (Perkin-Elmer) and template DNA in a total volume of $25 \mu$. The reaction mixtures were overlaid with mineral oil and cycled in a DNA Thermal Cycler (Perkin- 
Elmer) 35 times at $94^{\circ} \mathrm{C}$ for $1 \mathrm{~min}, 50^{\circ} \mathrm{C}$ for $1 \mathrm{~min}$, and $72^{\circ} \mathrm{C}$ for 3 min with a final extension at $72^{\circ} \mathrm{C}$ for $5 \mathrm{~min}$, resulting in amplification of a 564 base pair (bp) product. An aliquot (usually $10 \%$ of reaction volume) of each PCR reaction was checked for amplification product by agarose gel electrophoresis and ethidium bromide staining. The identity of the PCR product was confirmed by digestion with the restriction endonucleases Ban I, Nsi I, and Sal I, each of which had 1 recognition site predicted by the sequence data (see Fig. 1) Ten-fold serial dilutions from $1 \mathrm{ng}$ to $1 \mathrm{fg}$ of cloned Haplosporidium nelsoni SSU rDNA were used to determine the sensitivity of the primers to homologous target DNA.

Primer specificity was tested in PCR reactions using genomic DNA from oysters infected and not infected with Haplosporidium nelsoni, and cloned SSU rDNA of 3 haplosporidians, $M$. teredinis, Haplosporidium costale, and Haplosporidium louisiana. The putative uninfected oyster PCR reaction contained $500 \mathrm{ng}$ genomic oyster DNA isolated from gill and mantle tissue of an oyster collected from Ross Rock, Rappahannock River, VA, USA, in September 1989. Historically $H$. nelsoni has not been present at this low salinity location; the oyster was also diagnosed as negative for Perkinsus marinus by fluid thioglycollate medium (FTM) assay. The infected oyster PCR reaction contained 50 ng genomic oyster DNA isolated from gill and mantle tissue of an oyster collected from monitoring trays at the Virginia Institute of Marine Science (VIMS) in September 1992. The oyster had a heavy infection of $H$. nelsoni, as determined by examination of hemolymph (Burreson et al. 1988), and a very light infection of $P$. marinus, as determined by FTM assay. The genomic DNAs of $H$. costale, $H$. louisiana, and $M$. teredinis were isolated from purified spores as described previously (Stokes et al. 1995) and the SSU rRNA genes were amplified from the genomic DNAs and cloned, as described for $H$. nelsoni (Stokes \& Burreson 1995). H. costale spores were isolated from infected oysters collected from Wachapreague, VA, in June 1991, H. louisiana spores were isolated from infected mudcrabs (Panopeus spp.) collected at VIMS in September 1991, and $M$. teredinis spores were isolated from infected shipworms (Teredo spp.) collected from a tidal creek at Wachapreague in September 1991. The PCR reactions contained $10 \mathrm{ng}$ cloned SSU rDNA of each of the above haplosporidians.

Haplosporidium nelsoni diagnosis. To compare the diagnostic capabilities of the $H$. nelsoni PCR primers and the established techniques of histological examination and hemolymph settlement analysis using Farley chambers (Burreson et al. 1988), 20 oysters were tested using all 3 techniques to determine $H$. nelsoni presence in each individual. The oysters were collected from Deep Water Shoal, James River, VA, in May 1994 and held in trays off of the VIMS pier in the York River until sampled in October 1994. Oyster valves were notched and approximately $0.5 \mathrm{ml}$ hemolymph was extracted from the adductor muscle sinus for use with hemolymph settlement analysis and PCR. The oysters were then shucked, tissues fixed in Davidson's AFA and embedded in paraffin, and $5 \mu \mathrm{m}$ thick transverse sections were cut through the visceral mass, mantle, and gills of each individual. Tissue sections were stained with Harris hematoxylin and eosin ( $\mathrm{H} \& \mathrm{E})$ and coverslipped for histological examination. For hemolymph settlement analysis, 2 drops $(<50 \mu l)$ of hemolymph were added to $1 \mathrm{ml}$ of $0.2 \mu \mathrm{m}$ filtered York River water in a Farley chamber attached to a glass slide and allowed to settle for $1 \mathrm{~h}$ at room temperature. Two drops of hemolymph is about the maximum amount that can be used and still assure a monolayer of cells on the slide. The adherent cells were fixed in Dietrich's AFA, stained with Harris $H \& E$, and coverslipped. Cells in the remaining hemolymph were washed with TE buffer (10 mM Tris, pH 8.0,1.0 mM EDTA), resuspended in lysing solution $(50 \mathrm{mM}$ Tris, pH 8.0, $100 \mathrm{mM}$ EDTA, $1 \%$ sarkosyl, $0.5 \mathrm{mg} \mathrm{ml}^{-1}$ proteinase $\mathrm{K}$ ) and incubated overnight at $55^{\circ} \mathrm{C}$. Nucleic acids were recovered with phenol extraction and ethanol precipitation using 0.2 M NaCl (Sambrook et al. 1989). Samples were purified using an ethidium bromide/high salt extraction (Stemmer 1991), resuspended in $20 \mu \mathrm{ld} \mathrm{H}_{2} \mathrm{O}$, and $5 \mu$ used for PCR amplification. To determine if reamplification would increase the sensitivity of the assay, $1 \mu l$ of the unpurified PCR product was used as the template in a second PCR reaction.

\section{RESULTS}

\section{Primer sensitivity and specificity}

The PCR primer pair MSX-A and MSX-B amplified a 564 bp region of the Haplosporidium nelsoni small subunit rRNA gene (Fig. 1). The 564 bp product was easily detectable after PCR amplification using $100 \mathrm{fg}$ $H$. nelsoni cloned rDNA; $10 \mathrm{fg}$ cloned rDNA also yielded the expected product, but the band was very faint in the agarose gel (Fig. 2). Agarose gel electrophoresis of the restriction-endonuclease-digested PCR product yielded the expected fragment sizes of $227 \mathrm{bp}+$ $337 \mathrm{bp}$ for Ban I, $117 \mathrm{bp}+447 \mathrm{bp}$ for Nsi I, and $224 \mathrm{bp}+$ 340 bp for Sal I, as predicted by the sequence information, and confirmed the identity of the product as H. nelsoni (Figs. 1 \& 3).

The primers amplified the Haplosporidium nelsoni SSU IDNA from $50 \mathrm{ng}$ of genomic DNA from an oyster infected with $H$. nelsoni, but they did not generate a 


\begin{abstract}
aacctggttg atectgccag tagtcatatg ctgtctcaa agattaagoc atgcatgtoc aagtataaac aogttttgta ctgtgaalect: gcagatggct cattacaaca gttataatth atttggaatg taakattact oggataacog tactaactct agggctaata cgtgataaat ggtacgtgtt agtcaaaac catcattggt tgatatataa cattgcttcc gatcogtgg grtaaaaacc agogacaaat cattcaagt: tetgoctat cagcttgaog gtaggatatg ggcctacogt gjctatgacg ggtaacgggg aatcagggtt ogattcogga gaggcagoct gagaaayge taccacatcc acggacggca gcaggtgcge aaattaccea cttctgactc agagaggtag tgacaagaca taacgatgtg cagoctatgg ttgoctagtc gtaatgagaa caattraaa tcartatcoa ctaacaagtg gagggcaagt ctggtgccag cagcogcgta ataccagctc cactagcgta tactaaagtt getgctgtta aaaagctogt agttggatat cagttatgtg agogtggaca gggtgtgtat: acattcggga tocagacaac ttttgttgge tcaccaact: taattcagga ctgccattct gaccatttct gtggeteggg ttggogtgtc ctgatcttt acttrgagad aattaaagtg ctcaaagcag gctttogct gaatgcatra gcatggaata ataaaacacg actteg

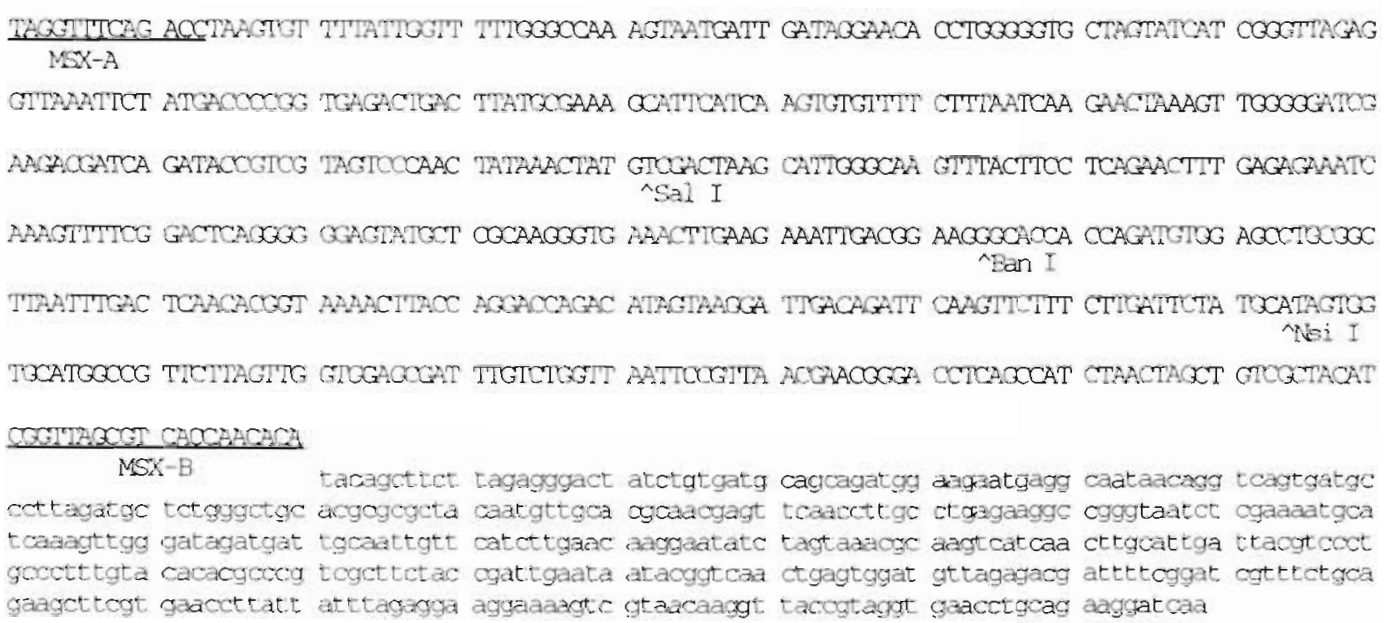

Fig. 1. Haplosporidium nelsoni complete 16S-like rDNA gene sequence. Amplified fragment is in upper case; primer regions for MSX-A and MSX-B are underlined. ${ }^{\wedge}$ : Predicted digestion sites for Sal I, Ban I and NSi I

PCR product from $500 \mathrm{ng}$ of genomic DNA from an oyster not infected with $H$. neIsoni (Fig. 3). The primers did not amplify the SSU rDNA from the haplosporidians $H$. costale, H. louisiana, or $M$. teredinis (Fig. 3).

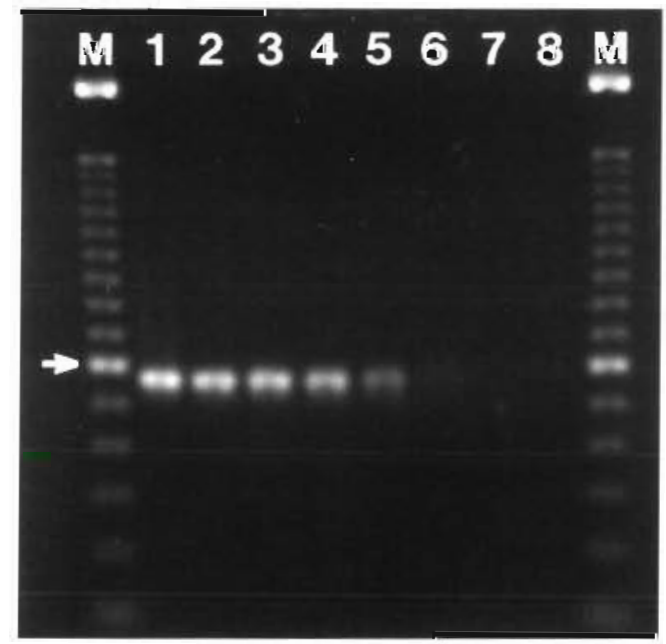

Fig. 2. Agarose gel electrophoresis of amplification products using primers MSX-A and MSX-B against serial dilutions of cloned Haplosporidium nelsoni SSU rDNA template. Lanes M: $100 \mathrm{hp} \mathrm{ladder} \mathrm{size} \mathrm{markers,} \mathrm{arrow} \mathrm{indicates} 600 \mathrm{bp}$; Lane $1: 1 \mathrm{ng}$ template DNA; Lane 2: 100 pg; Lane 3: $10 \mathrm{pg}$; Lane 4: $1 \mathrm{pg}$; Lane 5: $100 \mathrm{fg}$ i Lane 6: $10 \mathrm{fg}_{i}$ Lane 7: $1 \mathrm{fg}$; Lane 8: no DNA control

\section{Diagnosis comparison}

Haplosporidium nelsoni was detected by all 3 techniques of hemolymph settlement analysis, histological examination of tissue, and amplification from hemolymph with the PCR primers MSX-A and MSX-B (Table 1). Hemolymph settlement analysis indicated that only 10 of 20 oysters were infected, while histological examination detected 11 infected oysters. Histological examination detected infections in 3 oysters that were diagnosed as negative by hemolymph settlement, but also diagnosed 2 oysters as uninfected that were reported with rare infections by hemolymph settlement. Intensity of infection determined by hemolymph settlement analysis was often lower than that by histological examination of the same oyster. PCR amplification of DNA from hemolymph of infected oysters yielded the 564 bp PCR product of $H$. nelsoni (Fig. 4), which was confirmed by the expected restriction endonuclease patterns described above. Amplification of the hemolymph DNA initially detected 15 infections, but reamplification of these $\mathrm{PCR}$ products detected 4 additional infections. Of the 4 infections not detected in the first round of amplification, 2 were negative and 2 were light infections as rated by histological examination; all 4 were negative by hemolymph settlement analysis. 


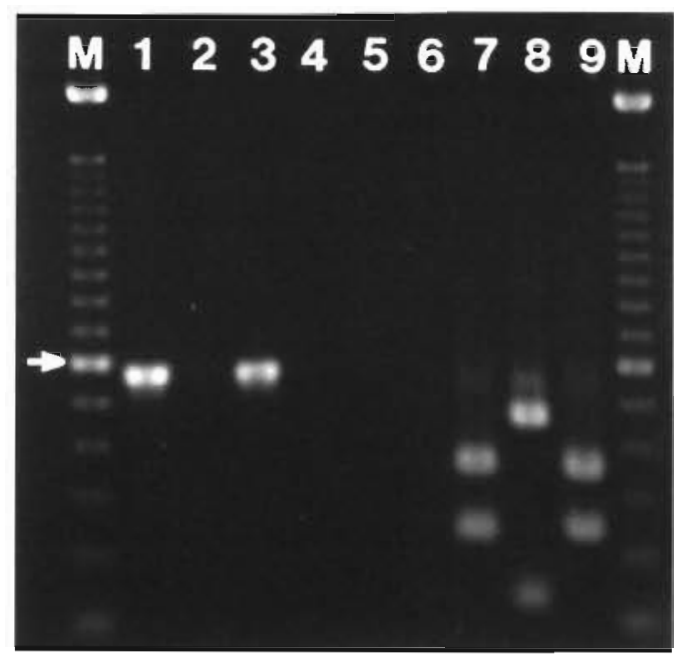

Fig. 3. Agarose gel electrophoresis of amplification products demonstrating specificity of PCR using primers MSX-A and MSX-B and various DNA templates. Lanes $M$ : 100 bp ladder size marker, arrow indicates $600 \mathrm{bp}$; Lane $1.100 \mathrm{pg}$ cloned Haplosporidium nelsoni SSU rDNA; Lane 2: $500 \mathrm{ng}$ uninfected oyster genomic DNA; Lane 3: $50 \mathrm{ng} H$. nelsoni-infected oyster genomic DNA; Lane 4: $10 \mathrm{ng}$ cloned $H$. costale SSU rDNA; Lane 5: $10 \mathrm{ng}$ cloned $H$. louisiana SSU rDNA; Lane 6: $10 \mathrm{ng}$ cloned Minchinia teredinis SSU rDNA; Lanes 7-9: PCR product of Lane 1 digested with Ban I, Nsl I, and Sal I, respectively
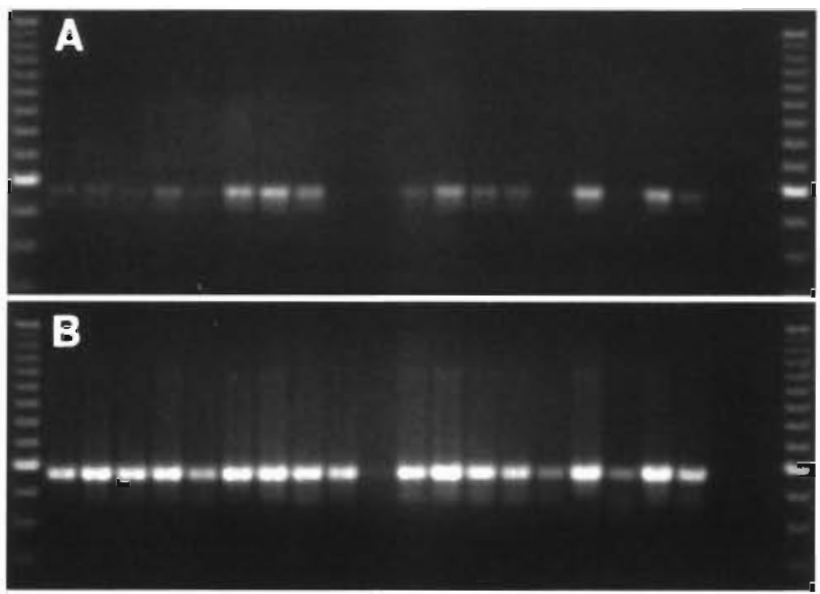

Fig. 4. Agarose gel electrophoresis of amplification products of oyster hemolymph with the MSX-A and MSX-B primers for Haplosporidium nelsoni diagnosis of the oyster samples shown in Table 1. (A) First PCR amplification using $5 \mu$ purified hemolymph lysate DNA. (B) Reamplification using $1 \mu l$ unpurified PCR product. For both gels, outside lanes are 100 bp ladder size markers; inside lanes are oyster samples 1 to 20 and no DNA control

\section{DISCUSSION}

Table 1. Comparison of diagnostic techniques for Haplosporidium nelsoni in oysters. PCR diagnosis recorded as (+) if the 564 bp $H$. nelsoni amplification product was present on the agarose gel and (-) if no amplification product was present on the agarose gel. PCR 1. first amplification: PCR 2: reamplification

\begin{tabular}{|cclcc|}
\hline $\begin{array}{c}\text { Oyster } \\
\text { number }\end{array}$ & $\begin{array}{c}\text { Hemolymph } \\
\text { analysis }\end{array}$ & Histology & PCR 1 & PCR 2 \\
\hline 1 & Negative & Moderate & + & + \\
2 & Heavy & Heavy & + & + \\
3 & Light & Heavy & + & + \\
4 & Light & Moderate & + & + \\
5 & Negative & Negative & + & + \\
6 & Heavy & Heavy & + & + \\
7 & Heavy & Heavy & + & + \\
8 & Rare & Negative & + & + \\
9 & Negative & Light & - & + \\
10 & Negative & Negative & - & + \\
11 & Negative & Negative & + & + \\
12 & Heavy & Heavy & + & + \\
13 & Negative & Negative & + & + \\
14 & Rare & Negative & + & + \\
15 & Negative & Negative & - & + \\
16 & Moderate & Heavy & + & + \\
17 & Negative & Light & - & + \\
18 & Light & Light & + & + \\
19 & Negative & Negative & + & + \\
20 & Negative & Negative & - & - \\
Total infected & 10 & 11 & 15 & 19 \\
Total uninfected & 10 & 9 & 5 & 1 \\
& & & & + \\
\hline
\end{tabular}

The PCR primers MSX-A and B are sensitive and specific for Haplosporidium nelsoni SSU rDNA. The 564 bp PCR product was easily detectable by agarose gel electrophoresis from a single amplification of $100 \mathrm{fg}$ of cloned $H$. nelsoni SSU rRNA gene, whereas $10 \mathrm{ng}$ of cloned SSU rDNA of $H$. costale, $H$. louisiana, or Minchinia teredinis, which is a $10^{5}$-fold increase, yielded no amplification products. These 4 haplosporidians represent the known species of Haplosporidium and Minchinia in the middle Atlantic region of the U.S. The primers were also able to amplify the $H$. nelsoni SSU IDNA fragment from total DNA extracted from tissue or hemolymph of an infected oyster.

The sensitivity of the amplification reaction to the presence of less than $100 \mathrm{fg}$ of cloned template DNA suggests that this technique could detect a very small number of Haplosporidium nelsoni organisms in an isolate The utility and sensitivity of these primers are due to features of the target SSU IRNA gene; hundreds of copies of this gene are usually present in the genome of any given \& Dixon 1991). Thus, these primers should be sensitive to the presence of orders of magnieukaryotic species (Appels et al. 1980, Hillis tude fewer infecting organisms than primers 
directed at single-copy genes. There is also increased sensitivity over that obtained by use of in situ hybridization techniques. Stokes \& Burreson (1995) reported that the probe MSX1347 (which targets the same site as the primer MSX-B) required approximately $100 \mathrm{pg}$ of cloned $H$. nelsoni SSU rDNA template to detect its presence in dot-blot preparations. Use of this oligonucleotide as a primer in conjunction with the upstream MSX-A primer in amplification reactions increases the limit of detection to a thousandth of that afforded by the probe alone.

For maximal sensitivity, diagnosis of Haplosporidium nelsoni in oysters by PCR amplification of a portion of the SSU rRNA gene was superior to microscopic examination of stained tissue or hemolymph. Reamplification of the PCR product greatly increased sensitivity and usefulness of the assay. Agarose gel electrophoresis has a detection limit of 1 to $2 \mathrm{ng}$ of ethidiumbromide-stained DNA (Sambrook et al. 1989). The 4 oyster samples which were diagnosed as negative for $H$. nelsoni after the first PCR reaction but positive after the second reaction probably contained such light infections that visualization of the amplified products was below the detection level of the stained gel. This conclusion was supported by the histological results that 2 of those 4 had light infections.

Reamplification of the oyster hemolymph samples with MSX-A and MSX-B increased the sensitivity of detection, but reamplification would also be more specific with the use of nested primers. Nested PCR consists of 2 rounds of amplification in which the second set of primers hybridize to internal sequences of the product generated from the first PCR reaction. In the PCR, primer-template complementarity is crucial for the $3^{\prime}$ end of the primer while poor homology with the $5^{\prime}$ end is allowed, so that some of the sequences amplified in the first $\mathrm{PCR}$ reaction may actually be nontarget DNA (Molina et al. 1994). The second amplification with nested primers increases detection specificity as the PCR product of only the target DNA segment is subject to reamplification. Reamplification with nested primers also eliminates the need to confirm the product identity with restriction endonuclease digestion as we had to do since both amplifications were done with the same primers.

One drawback to the Haplosporidium nelsoni diagnostic PCR assay as described is that, beyond a rough estimate, it is not quantitative. Efficiency of the PCR is dependent on factors such as target sequence abundance in the sample and the presence of inhibitors (Noonan et al. 1990, Piatak et al. 1993). Thus, because of the exponential amplification of the target, small variations in the amount of template or inhibitors can lead to large differences in product yield (Gilliland et al. 1990, Piatak et al. 1993). Furthermore, high and very high concentrations of target sequence are not distinguishable by gel electrophoresis due to the limiting nature of primers within the PCR. Thus, intensity of an ethidium-bromide-stained band of PCR product in a gel is not a good measure of infection intensity. However, methods have been developed to quantitate the template used for PCR amplification. The technique of quantitative competitive PCR (QC-PCR) allows very sensitive quantitation of the target sequence with the use of a second template which is amplified by the same primers in the PCR reaction, but whose product can be distinguished from that of the target (Gilliland et al. 1990, Piatak et al. 1993, Siebert \& Larrick 1993).

Unlike paraffin histology, amplification of Haplosporidium nelsoni SSU rDNA target sequence from oyster hemolymph is a nonlethal technique, facilitating sampling of the same animals repeatedly. A disadvantage of this technique is that parasite cells must be present in the hemolymph if they are to be detected; however, $H$. nelsoni is found in the hemolymph only in systemic infections (Ford \& Haskin 1982). Thus, oysters with localized infections may be diagnosed as false negatives. Nonsystemic, localized infections occur throughout the year (Ford \& Haskin 1982); hemolymph diagnosis using the settlement technique misses most of these infections, especially early in the infection process (Burreson et al. 1988, Ford \& Kanaley 1988). False negatives may result because of the small volume of hemolymph $(<50 \mu l)$ required in the settlement technique to assure a monolayer of cells. Nevertheless, on the basis of our results, PCR amplification of hemolymph is more sensitive than hemolymph settlement. Equal amounts of hemolymph were not used in the 2 assays, but both techniques were optimized for maximum sensitivity. This comparison may be biased because oysters were sampled at a time of year when a high proportion of infections are systemic. Future comparisons that include a seasonal component will be conducted to determine the utility of PCR hemolymph diagnosis at various times in the infection cycle.

The most obvious solution to detecting localized infections is to isolate total DNA from the entire animal, but then the technique becomes lethal and the amount of DNA in an adult oyster is substantial and would have to be greatly diluted to avoid 'swamping' the PCR reaction. The small amount of target DNA in a very high amount of host DNA results in loss of PCR sensitivity, possibly because of decreased potential for primer-template contact and binding (Zimmermann et al. 1994). However, total DNA isolation and amplification from a spat or small seed oyster seems feasible

PCR amplification of parasite DNA provides a sensitive presence/absence indicator of infection and would be valuable in a number of practical situations. Move- 
ment of infected oysters has been instrumental in the spread of Perkinsus marinus and possibly of Haplosporidium nelsoni (Ford 1992). Screening of oyster samples with PCR primers specific for these pathogens prior to importation will identify infected specimens with greater sensitivity than the currently prescribed methods. A negative result from either histological examination or PCR amplification of hemolymph does not necessarily indicate absence of $H$. nelsoni infection; however, the more sensitive PCR assay offers a better chance of detecting low intensity infections than do traditional techniques.

The use of PCR detection of Haplosporidium nelsoni, and ultimately of other oyster disease agents, should also prove useful for spat certification in the aquaculture industry. Negative diagnoses based on histological examination of spat tissue may not accurately reflect the disease status of the animals, but rather indicate only that the subsection of tissue examined had no recognizable pathogens. Greater sensitivity of disease detection would mean greater protection to the growers purchasing such spat. Because of the small size of spat, genomic DNA would be extracted and PCR-amplified from lysate of the entire spat, instead of an aliquot of hemolymph, thus assuring detection of all infections.

The complete life history is not known for any haplosporidian species and we plan to use the PCR primers and DNA probe to elucidate the Haplosporidium nelsoni life cycle. Lack of success in transmission experiments with spores of $H$. nelsoni in oysters has led to speculation that intermediate hosts may be required for completion of the life cycles in the Haplosporidia (Andrews 1984, Burreson 1988, Haskin \& Andrews 1988). The sensitivity of the PCR primers and their ability to selectively amplify $H$. nelsoni DNA from mixed host and parasite genomic DNA isolates should allow rapid screening of a large number of potential intermediate hosts for $H$. nelsoni. Unlike paraffin histology, PCR diagnosis does not require any knowledge of parasite morphology. Once an intermediate host species is identified, the specific $H$. nelsoni DNA probe would be used on paraffin sections to localize the parasite in the host for subsequent morphological studies.

Acknowledgements. We thank Sandra Blake for technical assistance with PCR reactions and Juanita Walker for histological preparation and examination. Lisa Ragone Calvo and Sandra Blake provided valuable comments on the manuscript. This research was funded in part by the NOAA Oyster Disease Research Program under grant numbers NA90AADFM742 and NA26FL0379-01 and by a Natural Sciences and Engineering Research Council of Canada Postdoctoral Fellowship to M.E.S. VIMS contribution number 1967

\section{LITERATURE CITED}

Andrews JD (1964) Oyster mortality studies in Virginia. IV. MSX in James River public seed beds. Proc natl Shellfish Assoc 53:65-84

Andrews JD (1984) Epizootiology of diseases of oysters (Crassostrea virgmica), and parasites of associated organisms in eastern North America. Helgolander Meeresunters 37 : $149-166$

Appels R, Gerlach WL, Dennis ES, Swift H, Peacock WJ (1980) Molecular and chromosomal organization of DNA sequences coding for the ribosomal RNAs in cereals. Chromosoma 78:293-311

Bilofsky HS, Burks C (1988) The GenBank (R) genetic sequence data bank. Nucl Acids Res 16:1861-1864

Burreson EM (1988) Use of immunoassays in haplosporidian life cycle studies. In: Fisher WS (ed) Disease processes in marine bivalve molluscs. Am Fish Soc Spec Publ 18: $298-303$

Burreson EM, Robinson ME, Villalba A (1988) A comparison of paraffin histology and hemolymph analysis for the diagnosis of Haplosporidium nelsoni (MSX) in Crassostrea virginica (Gmelin). J Shellfish Res 7:19-23

Fong D, Chan MMY, Rodriguez R, Chen CC, Liang Y, Littlewood DTJ, Ford SE (1993) Small subunit ribosomal RNA gene sequence of the parasitic protozoan Haplosporidium nelsoni provides a molecular probe for the oyster MSX disease. Mol Biochem Parasitol 62:139-143

Ford SE (1985) Effects of salinity on survival of the MSX parasite Haplosporidium nelsoni (Haskin, Stauber, and Mackin) in oysters. J Shellfish Res 5:85-90

Ford SE (1986) Effect of repeated hemolymph sampling on growth, mortality, hemolymph protein and parasitism of oysters, Crassostrea virginica. Comp Biochem Physiol $85 \mathrm{~A}: 265-470$

Ford SE (1992) Avoiding the transmission of disease in commercial culture of molluscs, with special reference to Perkinsus marinus (Dermo) and Haplosporidium nelsoni (MSX). J Shellfish Res 11:539-546

Ford SE, Haskin HH (1982) History and epizootiology of Haplosporidium nelsoni (MSX), an oyster pathogen in Delaware Bay, 1957-1980. J Invertebr Pathol 40:118-141

Ford SE, Haskin HH (1988) Management strategies for MSX (Haplosporidium nelsoni) disease in eastern oysters. In: Fisher WS (ed) Disease processes in marine bivalve molluscs. Am Fish Soc Spec Publ 18:249-256

Ford SE, Kanaley SA (1988) An evaluation of hemolymph diagnosis for detection of the oyster parasite Haplosporidium nelsoni (MSX). J Shellfish Res 7:11-18

Gilliland G, Perrin S, Bunn HF (1990) Competitive PCR for quantitation of mRNA. In: Innis MA, Gelfand DH, Sninsky JJ, White TJ (eds) PCR protocols: a guide to methods and applications. Academic Press, Inc, San Diego, p 60-69

Haskin $\mathrm{HH}$, Andrews JD (1988) Uncertainties and speculations about the life-cycle of the eastern oyster pathogen Haplosporidium nelsoni (MSX). In: Fisher WS (ed) Disease processes in marine bivalve molluscs. Am Fish Soc Spec Publ 18:5-22

Hillis DM, Dixon MT (1991) Ribosomal DNA: molecular evolution and phylogenetic inference. Q Rev Biol 66:411-453

Hudson DA, Adlard RD (1994) PCR techniques applied to Hematodinium spp. and Hematodinium-like dinoflagellates in decapod crustaceans. Dis aquat Org 20:203-206

Innis MA, Gelfand DH (1990) Optimization of PCRs. In: Innis MA, Gelfand DH, Sninsky JJ, White TJ (eds) PCR protocols: a guide to methods and applications. Academic Press, Inc, San Diego, p 3-12 
Molina FI, Geletka LM, Jong SC, Zhang Y (1994) Use of a nested primer pair as control for PCR amplification of ribosomal DNA internal transcribed spacers in fungi. Biotechniques 16:998-1002

Noonan KE, Beck C, Holymayer TA, Chin JE, Wunder JS, Andrulis IL, Gadzar AF, Willman CL, Griffity B, Von Hoff DD, Roninson IB (1990) Quantitative evaluation of MDR1 (multidrug resistance) gene expression in human tumors by polymerase chain reaction. Proc natl Acad Sci USA 87 : $7160-7164$

Piatak M Jr, Luk KC, Williams B, Lifson JD (1993) Quantitative competitive polymerase chain reaction for accurate quantitation of HIV DNA and RNA species. Biotechniques $14: 70-81$

Sambrook J, Fritsch EF, Maniatis T (1989) Molecular cloning: a laboratory manual, 2nd edn. Cold Spring Harbor Laboratory Press, Cold Spring Harbor, NY

Siebert PD, Larrick JW (1993) PCR MIMICS: competitive

Responsible Subject Editor: A. K. Sparks, Seattle, Washington, USA
DNA fragments for use as internal standards in quantitative PCR. Biotechniques 14:244-249

Stemmer W (1991) A 20-minute ethidium bromide/high-salt extraction protocol for plasmid DNA. Biotechniques 10:726

Stokes NA, Burreson EM (1995) A sensitive and specific DNA probe for the oyster pathogen Haplosporidium nelsoni. J Eukaryot Microbiol 42:350-357

Stokes NA, Siddall ME, Burreson EM (1995) Small subunit ribosomal RNA gene sequence of Minchinia teredinis (Haplosporidia: Haplosporididae) and a specific DNA probe and PCR primers for its detection. $J$ Invertebr Pathol 65:300-308

Taylor PL (1993) GeneJockeyII. Sequence processor. BIOSOFT, Cambridge

Zimmermann K, Pischinger K, Mannhalter JW (1994) Nested primer PCR detection limits of HIV-1 in the background of increasing numbers of lysed cells. Biotechniques 17 : $18-20$

Manuscript first received: March 13, 1995

Revised version accepted: June 1, 1995 